Crop Breeding and Applied Biotechnology 14: 8-14 2014

Brazilian Society of Plant Breeding. Printed in Brazil

\title{
ARTICLE
}

\section{Agronomic performance of super-sweet corn genotypes in the north of Rio de Janeiro}

Pedro Henrique Araújo Diniz Santos ${ }^{1 *}$, Messias Gonzaga Pereira ${ }^{1}$, Roberto dos Santos Trindade ${ }^{2}$, Keila Silva da Cunha ${ }^{1}$, Geovana Cremonini Entringer ${ }^{1}$ and Julio Cesar Fiorio Vettorazzi ${ }^{1}$

Received 18 January 2012

Accepted 04 November 2013

\begin{abstract}
We investigated the agronomic performance of super-sweet corn genotypes. Super-sweet corn genotypes were backcrossed with regionally adapted field varieties (CIMMYT 8 and Piranão 8). Eight morphological and yield-related traits were evaluated. A significant effect of interaction was observed between the five groups of genotypes (donor parents; super-sweet backcrossed parents; super-sweet intervarietal hybrids; common intervarietal corn hybrids; and field corn populations). Despite the low yield of genotype SH Piranão, the hybrids resulting from interbreeding of the backcrossed parents for the improvement of super-sweet corn were promising. The agronomic performance of the super-sweet parents and their hybrids indicates the possibility of breeding lines with high genetic value to obtain single-cross hybrids and cultivars of super-sweet corn adapted to the northern region of the State of Rio de Janeiro.
\end{abstract}

Key words: Zea mays, super-sweet corn, intervarietal hybrids, heterosis, yield.

\section{INTRODUCTION}

Sweet corn (Zea mays L.), considered a vegetable, is a special type of corn with particular characteristics, such as sweet taste, thin pericarp and endosperm with delicate texture, and a high nutritional value (Kwiatkowski and Clemente 2007). It is destined exclusively for human consumption, in fresh form or in processed foods, whereas the straw can be used for silage after harvest (Teixeira et al. 2001). In Brazil, sweet corn is grown on an estimated 36 million ha annually, with an average yield of $10-12$ tons of ears. ha ${ }^{-1}$ (Barbieri et al. 2005, Kwiatkowski and Clemente 2007), although recent data on the crop yield are not available.

The difference between sweet and common corn is that in the genome of the former, at least one of the eight genes that influence carbohydrate biosynthesis in the endosperm is mutant, preventing the conversion of carbohydrate to starch (Tracy et al. 2006, Qi et al. 2009). These genes comprise: shrunken-2 (sh2), brittle (bt), Amylose Extender (ac), sugary enhancer (se), sugary (su), and Brittle-2 (bt2), "Dull” ( $d u)$, and Waxy (wx), all monogenic and recessive. Among the corn cultivars with high sugar contents, the super-sweet corn cultivars stand out with even higher levels of carbohydrates than the sweet corn varieties (Oliveira Júnior et al. 2006).
Brazil, for being a large producer of field corn, with an output of more than 58 million tons (CONAB 2011), also has great a potential for the production of super-sweet corn. However, the limited availability of super-sweet cultivars restricts their cultivation as well as the presence of this product on the market. Few super-sweet corn hybrids are available to the food-processing industries as well as farmers and consumers, indicating the need for the breeding of new cultivars (Bordallo et al. 2005). In addition, the expression of the super-sweet trait in corn is coupled with undesirable characteristics, e.g., reduced germination and low resistance to pests and diseases (Oliveira Júnior et al. 2006).

Given the above, it is clear that the way to the exploitation of super-sweet corn is through corn breeding, requiring the evaluation of the response of cultivars to environmental conditions, of the variability within and between the germplasm under study and the selection of superior genotypes for agronomic traits of interest (Nigussie and Saleh 2007, Revilla et al. 2010). For the improvement of sweet corn, two strategies can be applied: (1) The introduction of the "sweet" trait into a genotype with normal endosperm, adapted to the growth environment, or (2) the incorporation of sweet corn genotypes into a conventional breeding program (Bordallo

\footnotetext{
${ }^{1}$ Universidade Estadual do Norte Fluminense (UENF), Centro de Ciências e Tecnologias Agropecuárias, Laboratório de Melhoramento Genético Vegetal, Av. Alberto Lamego, 2000, Horto, 28.015-620, Campos dos Goytacazes, RJ, Brazil. *E-mail: phsantos2004@yahoo.com.br

${ }^{2}$ Embrapa Milho e Sorgo, Rod. MG 424, km 65, 35.701-970, Sete Lagoas, MG, Brazil
} 
et al. 2005, Butrón et al. 2008).

The purpose of this study was therefore to evaluate the agronomic performance of sweet corn and field corn genotypes for the identification of promising genotypes for the improvement of this crop for the northern region of the state of Rio de Janeiro.

\section{MATERIAL AND METHODS}

To breed super-sweet corn genotypes, we used two parents from the National Research Center for Maize and Sorghum (CNPMS) as donors of the "sweet" trait, both carriers of the gene shrunken-2 (sh2), namely: super-sweet synthetic $\mathrm{SH}_{2}$ and super-sweet synthetic $\mathrm{SH}_{2}-8 \mathrm{HS}$. These genotypes were crossed with field corn varieties of the groups CIMMYT 8 and Piranão 8 , after the eighth cycle of reciprocal recurrent selection of full-sib families of the breeding program of the UENF (State University of Norte Fluminense Darcy Ribeiro), resulting in four super-sweet varieties $\mathrm{SH}_{2}$ CIMMYT, $\mathrm{SH}_{2}$ Piranão, $\mathrm{SH}_{2}$-8HS CIMMYT, and $\mathrm{SH}_{2}-8 \mathrm{HS}$ Piranão). Thereafter, these four varieties were backcrossed for five generations with the varieties CIMMYT 8 and Piranão 8 , to recover the genome of the recurrent parents along with the super-sweet trait.

After establishing the four varieties of super-sweet corn, they were intercrossed, generating the following super-sweet intervarietal hybrids: $\mathrm{SH}_{2}$ Piranão x $\mathrm{SH}_{2}$ CIMMYT; $\mathrm{SH}_{2}$ Piranão x $\mathrm{SH}_{2}-8 \mathrm{HS}$ CIMMYT; $\mathrm{SH}_{2}-8 \mathrm{HS}^{2}$ Piranão x $\mathrm{SH}_{2}-$ 8HS CIMMYT, and $\mathrm{SH}_{2}$-8HS Piranão x $\mathrm{SH}_{2}$ CIMMYT.

For the competition assay, the donor parents character super-sweet, super-sweet genotypes resulting from backcross and their intervarietal hybrids were assessed Besides these intervarietal hybrids six genotypes originating from reciprocal recurrent selection program for corn UENF common were evaluated, namely the varieties CIMMYT 8, Piranão 8, CIMMYT 12 and Piranão 12, and two interpopulation hybrids of field corn, CIMMYT 8 x Piranão 8 and CIMMYT $12 \times$ Piranão 12 , with a total of 16 treatments.

The experiment was set up in August 2010 in a randomized complete block design, with five replications, at two evaluation sites: Colégio Agrícola Antônio Sarlo and an experimental field of the research partnership of PESAGRO/ RJ - UENF, in Campos dos Goytacazes. Each plot consisted of two 5-m-long rows, with plants spaced $0.3 \mathrm{~m}$ and rows 1 $\mathrm{m}$ apart, using four rows around the planting area as border area. Six seeds were sown per hole and thinned to one plant per hole 30 days later.

At the evaluation sites, 8-28-16 NPK fertilizer was applied at sowing at a dose of $400 \mathrm{~kg}$ $\mathrm{ha}^{-1}$, and 20 grams of urea per meter was topdressed 20 and 40 days after sowing. The field corn plants were emasculated at the end of the transitional stage (VT) to prevent the xenia effect. Irrigation and other cultural practices were applied according as recommended for corn (Fancelli and Dourado Neto 2000).

The plants were assessed between the stages R4 and R5 (Fancelli and Dourado Neto 2000), when the ears were still green, 22 days after pollination, for the traits: plant height in meters (PH), number of plants per plot (DENS), days to female flowering (DFF); ear yield, in $\mathrm{t} \mathrm{ha}^{-1}$ (YIELD), mean length of unhusked ears (EL); diameter of unhusked ears (ED), number of ears per plot (NEP) and number of ears attacked by pests (NEAP). The trait DENS was not corrected, since the difference among genotypes for this trait was significant, indicating genetic and not only environmental causes, justifying the non-correction of the plot yields. It is also worth mentioning that the data of NEAP were not normally distributed and therefore subjected to analysis of variance.

In the statistical analysis, the data were initially subjected to analysis of variance, considering the effects of the statistical model as fixed. The effects of genotype, location and group (super-sweet donor parents; field corn populations; backcrossed super-sweet parents; intervarietal field corn hybrids and intervarietal super-sweet hybrid) were evaluated, as well as the interactions of these effects with the location (Table 1). Then the mean yield among and within the five groups of genotypes under study was analyzed by the least significant difference (LSD) and based on agronomic traits, evaluated in the different genotype groups by orthogonal contrasts.

In addition to these analyses, we estimated the determination coefficient $\left(\mathrm{H}^{2}\right)$, the coefficients of genotypic and experimental $\left(\mathrm{CV}_{\mathrm{g}}\right.$ and $\mathrm{CV}_{\mathrm{e}}$, respectively) variation, the index of genotypic variation and selection accuracy, as described by Resende and Duarte (2007). All analyses were performed with SAS Institute software (1996).

\section{RESULTS AND DISCUSSION}

The results of the analysis of variance for the effects of genotype and location for all studied traits (Table 1) indicated significant differences $(P \leq 0.01)$ between the location of cultivation and genotypes.

The effects for the sources of variation between groups were significant (super-sweet donor parents; field corn populations; super-sweet backcrossed parents; intervarietal field corn hybrids and super-sweet intervarietal hybrids) for all traits (Table 1), discriminating the groups clearly and reinforcing the consistency of the partitioning of the genotypes in different groups.

At the intra-group level, no significant differences were 
observed among donors for all agronomic characteristics evaluated (Table 1). The field corn varieties used as recurrent parents differed significantly in the traits YIELD, EL, ED, NEP, and NEAP, indicating differences in yield among the evaluated populations, which may be directly related to the number of recurrent selection cycles applied to these genotypes. With regard to the group of field corn hybrids, differences were only found for DENS and EL.

With the exception of DFF, significant differences were observed for all morpho-agronomic traits of the four parents backcrossed to super-sweet corn. This indicates that the conversion of the genotypes CIMMYT 8 and Piranão 8 to super-sweet corn was efficient in establishing new sweet corn genotypes clearly distinct from the original parents.
Differences were observed for the characteristics $\mathrm{PH}$ and DENS between the super-sweet hybrids and common corn. The variations in DENS for the genotypes containing the $s h 2$ gene may be related to failure in germination, which is a common problem, particularly in varieties with the super-sweet trait. Cultivars with the sh 2 gene have a high content of soluble sugars and a low conversion rate to starch, reducing its reserves in the endosperm, aside from a softer pericarp (Welbaum et al. 2001). These factors contribute to reduce seed vigor and germination and accelerate the loss of seed viability, resulting in poor plant density (Aragão et al. 2003, Reis et al. 2011).

Despite the difference observed between the locations for all traits, no effects were detected for genotype - loca-

Table 1. Estimates of mean squares of 16 genotypes of Zea mays L. and their five respective groups were evaluated at two locations (Colégio Agrícola e Estação Experimental da Pesagro) in Campos dos Goytacazes, state of Rio de Janeiro, in the 2010/2011 growing season

\begin{tabular}{|c|c|c|c|c|c|c|c|c|c|c|}
\hline \multirow{2}{*}{ Source of variation } & \multirow{2}{*}{ df } & & \multicolumn{8}{|c|}{ Mean squares } \\
\hline & & & $\mathbf{P H}$ & DENS & DFF & YIELD & EL & ED & NEP & NEAP $^{1}$ \\
\hline Block/Location & 8 & & $585.29^{* *}$ & 6.43 & 20.98 & 29.61 & 0.68 & 1.98 & 62.82 & 0.27 \\
\hline Location & 1 & & $2999.92 * *$ & $861.12 * *$ & $457.53 * *$ & $605.12 * *$ & $18.35^{* *}$ & $8.86^{*}$ & $4163.28 * *$ & $7.81 * *$ \\
\hline Genotypes & 15 & & $913.09 * *$ & $251.06^{* *}$ & $67.43 * *$ & $243.04 * *$ & $9.04 * *$ & $13.30 * *$ & $627.75^{* *}$ & $1.67 * *$ \\
\hline SSPD & & 1 & 54.39 & 22.56 & 25.00 & 49.70 & 0.10 & 0.09 & 60.06 & 0.97 \\
\hline FCP & & 3 & 133.15 & 2.83 & 37.61 & $49.90 *$ & $7.99 * *$ & $14.63 * *$ & $216.61 * *$ & $1.61^{* *}$ \\
\hline $\mathrm{SSH}$ & & 3 & $357.19 * *$ & $68.36 * *$ & 24.28 & 5.36 & 0.53 & 0.87 & 48.11 & 0.57 \\
\hline Groups & & 4 & $2793.53 * *$ & $290.64 * *$ & $168.03 * *$ & $552.06^{* *}$ & $18.94 * *$ & $21.54 * *$ & $1086.35^{* *}$ & 3.43 \\
\hline Gen $x$ Location & 15 & & $318.72 * *$ & $20.30 * *$ & 18.89 & 20.95 & 0.74 & $4.81 * *$ & 84.49 & 0.44 \\
\hline SSPD $x$ Location & & 1 & 23.76 & 3.06 & 20.25 & $63.20 *$ & 0.01 & 0.03 & $280.56^{*}$ & 0.15 \\
\hline FCP $x$ Location & & 3 & $223.37 *$ & 8.45 & 1.78 & 16.83 & 0.01 & 0.59 & 18.36 & 0.63 \\
\hline Groups x Location & & 4 & $861.44 * *$ & 11.67 & $48.46^{* *}$ & 4.45 & $1.89^{* *}$ & $6.94 * *$ & 108.90 & 0.83 \\
\hline Error & 90 & & 77.67 & 8.90 & 10.57 & 15.46 & 0.65 & 1.93 & 52.61 & 0.41 \\
\hline Total & 127 & & & & & & & & & \\
\hline
\end{tabular}

*,** Significant at 5 and $1 \%$ by the F test, respectively; SSPD $=$ Super-sweet parent donors, FCP = field corn populations; FCH = field corn hybrids; PBSS = parents backcrossed to super-sweet corn, $\mathrm{SSH}=$ super-sweet hybrid; Gen = genotype, $\mathrm{PH}=$ plant height, $\mathrm{DENS}=$ number of plants per plot, $\mathrm{DFF}=$ days to flowering; YIELD = yield $\left(\mathrm{t} \mathrm{ha}^{-1}\right) ; \mathrm{EL}=$ ear length; $\mathrm{ED}=$ ear diameter; $\mathrm{NEP}=$ number of ears; NEAP $=$ number of ears attacked by pests. ${ }^{1}$ Data transformed to $(\mathrm{x}+0.5)^{1 / 2}$ for analysis of variance.

Table 2. Overall mean $(\overline{\mathrm{X}})$ and experimental parameters of 16 genotypes at two locations (Colégio Agrícola e Estação Experimental da Pesagro) in Campos dos Goytacazes, state of Rio de Janeiro, in the 2010/2011 growing season

\begin{tabular}{|c|c|c|c|c|c|c|c|c|}
\hline Experimental parameters & $\mathbf{P H}$ & DENS & DFF & YIELD & EL & ED & NEP & NEAP $^{1}$ \\
\hline$\overline{\mathrm{X}}$ & 165.18 & 33.54 & 77.98 & 32.12 & 20.17 & 26.04 & 56.06 & 5.59 \\
\hline $\mathrm{H}^{2}$ & 91.49 & 96.45 & 74.34 & 93.64 & 92.80 & 85.48 & 91.61 & 75.22 \\
\hline $\mathrm{CV}_{\mathrm{g}}$ & 6.18 & 16.40 & 3.20 & 16.60 & 5.07 & 4.57 & 15.12 & 14.55 \\
\hline $\mathrm{CV}_{\mathrm{e}}$ & 5.33 & 8.89 & 5.33 & 12.14 & 3.99 & 5.33 & 12.93 & 23.61 \\
\hline IV & 1.15 & 1.84 & 0.60 & 1.35 & 1.26 & 0.85 & 1.16 & 0.62 \\
\hline AS* & 0.90 & 0.97 & 0.80 & 0.95 & 0.90 & 0.90 & 0.90 & 0.85 \\
\hline
\end{tabular}

$\mathrm{H}^{2}=$ genotypic determination coefficient; $\mathrm{CV}=$ coefficient of genotypic variation; $\mathrm{CV}=$ coefficient of experimental variation; IV = index of genotypic variation; AS * = selection accuracy considering the genotype effect on analysis of variance; $\mathrm{PH}=$ plant height; DENS = number of plants per plot; DFF = days to flowering; YIELD = yield $\left(\mathrm{t} \mathrm{ha} \mathrm{a}^{-1}\right) ; \mathrm{EL}=$ ear length; $\mathrm{ED}=$ ear diameter; NEP $=$ number of ears; NEAP $=$ Number of ears attacked by pests. ${ }^{1}$ Data transformed to $(\mathrm{x}+0.5)^{1 / 2}$ for analysis of variance. 
tion interaction (GL) for the traits evaluated, except for $\mathrm{PH}, \mathrm{DENS}$ and ED, nor for the group - location interaction, except for PH, DFF, EL, and ED (Table 1). The fact that significant differences were observed for the simpler traits with regard to the GL interaction may be related to the fact that these characters are controlled by few genes and therefore strongly influenced by the environment, indicating a qualitative character, altering the ranking of the evaluated genotypes in the different locations. However, for more complex traits such as YIELD, the environmental effect becomes weaker with regard to the qualitative traits, since many genes are involved, resulting in a coincident ranking of the treatments in the different locations.

In the specific case of the group - location interaction, there were significant differences $(P \leq 0.01)$ for half of the traits (PH, DFF, EL, and ED), indicating that the groups performed differently in the dif- ferent locations. For the rest of the traits no group - location interaction was detected. It may therefore be concluded that the groups performed similarly in the evaluated locations.

The traits YIELD and NEP are considered the most important to evaluate the agronomic performance of super-sweet corn (Butrón et al. 2008, Assunção et al. 2010, Revilla et al. 2010). Since no interaction with the location was detected for these traits, it is possible to recommend superior genotypes for the locations where they were tested.

In the overall means of the experiment (Table 2), the YIELD and NEP values were $32.12 \mathrm{tha}^{-1}$ and 56 ears plot ${ }^{1}$, respectively. These YIELD values are high, compared to the means reported by Oliveira Júnior et al. (2006) and Assunção et al. (2010), which were $13.38 \mathrm{t} \mathrm{ha}^{-1}$ and 12.93 $\mathrm{t} \mathrm{ha} \mathrm{a}^{-1}$. Although the overall mean YIELD values resulted from both super-sweet corn and field corn genotypes, this

Table 3. Average ear yield ( $\left.\mathrm{t} \mathrm{ha}^{-1}\right)$ of genotypes, grouped according to their parents (CIMMYT 8-C8, Piranão 8-P8, CIMMYT 12-C12, Piranão 12-P12, super-sweet synthetic $\mathrm{SH}_{2}$-SSS Sh , and super-sweet synthetic $\mathrm{SH}_{2} 8 \mathrm{HS}-\mathrm{SSS} \mathrm{SH} \mathrm{S}_{2} 8 \mathrm{HS}$ ) at two locations (Colégio Agrícola Antônio Sarlo and Pesagro) in Campos dos Goytacazes, state of Rio de Janeiro, in the 2010/2011 growing season

\begin{tabular}{|c|c|c|c|}
\hline & $\begin{array}{l}\text { Colégio } \\
\text { Agrícola }\end{array}$ & Pesagro & Mean \\
\hline \multicolumn{4}{|l|}{ Super-sweet corn parent donors } \\
\hline $\mathrm{SSS} \mathrm{SH}_{2}$ & 31.77 & 22.84 & 27.31 \\
\hline Mean & 28.02 & 23.07 & 25.54 \\
\hline \multicolumn{4}{|l|}{ Field corn populations } \\
\hline C 12 & 39.85 & 33.76 & 36.80 \\
\hline P 12 & 34,40 & 33.31 & 33.85 \\
\hline Mean & 37.31 & 32.46 & 34.88 \\
\hline \multicolumn{4}{|l|}{ Field corn hybrids } \\
\hline $\mathrm{P} 8 \times \mathrm{C} 8$ & 37.55 & 33.97 & 35.76 \\
\hline \multicolumn{4}{|c|}{ Parents backcrossed to super-sweet corn } \\
\hline $\mathrm{SSS} \mathrm{SH}_{2}-\mathrm{P}$ & 21.30 & 12.62 & 16.96 \\
\hline $\mathrm{SSS} \mathrm{SH}_{2}-\mathrm{C}$ & 34.00 & 30.92 & 32.46 \\
\hline $\mathrm{SSS} \mathrm{SH}_{2} 8 \mathrm{HS}-\mathrm{P}$ & 29.80 & 28.29 & 29.04 \\
\hline $\mathrm{SSS} \mathrm{SH}_{2} 8 \mathrm{HS}-\mathrm{C}$ & 31.20 & 31.45 & 31.32 \\
\hline Mean & 29.07 & 25.82 & 27.44 \\
\hline \multicolumn{4}{|l|}{ Super-sweet intervarietal hybrids } \\
\hline $\mathrm{SSS} \mathrm{SH}_{2}-\mathrm{P} \times \mathrm{SSS} \mathrm{SH}_{2}-\mathrm{C}$ & 39.65 & 31.03 & 35.34 \\
\hline $\mathrm{SSS} \mathrm{SH}_{2}-\mathrm{P} \times \mathrm{SSS} \mathrm{SH}_{2} 8 \mathrm{HS}-\mathrm{C}$ & 37.00 & 31.66 & 34.33 \\
\hline $\mathrm{SSS} \mathrm{SH}_{2} 8 \mathrm{HS}-\mathrm{P} \times \mathrm{SSS} \mathrm{SH}_{2} 8 \mathrm{HS}-\mathrm{C}$ & 37.45 & 35.15 & 36.30 \\
\hline $\mathrm{SSS} \mathrm{SH}_{2} 8 \mathrm{HS}-\mathrm{P} \times \mathrm{SSS} \mathrm{SH}_{2}-\mathrm{C}$ & 35.75 & 35.51 & 35.63 \\
\hline
\end{tabular}

*LSD (least significant difference) calculated from the table value at $5 \%$ 
data indicates heterotic effects derived from the super-sweet hybrids obtained in this experiment, as well as the high agronomic value of the genotypes under study.

For DENS, the average of about 33 plants plot ${ }^{-1}$ suggests the loss of some plants in some treatments, since ideally the density is 50 plants plot $^{-1}$. This drop in germination shows the deleterious effects of gene $s h 2$ on germination. Welbaum et al. (2001) compared the response to transplanting seedlings with direct seeding of super-sweet corn genotypes containing gene $s h 2$, and found higher germination rates using transplanting, resulting in yields of $12.08 \mathrm{~kg} \mathrm{ha}^{-1}$ by transplanting versus $8.74 \mathrm{~kg} \mathrm{ha}^{-1}$ by direct seeding. In turn, Reis et al. (2011) observed heterosis effects in germination tests of $12: 56 \%$ for sweet corn hybrids and $15.62 \%$ for field corn hybrids, and the germination rate for both types of hybrids was above $85 \%$. In this context, it is clear that both the location and genotypic effects may be involved in the resulting final stand and in the yield of the super-sweet corn genotypes in this study.

The values of the determination coefficient ranged between 75.22 and 96.45 (Table 2). Although the genotype source of variation was regarded as fixed effect, these values are high, considering the experimental conditions. This indicates that the genotype performance at the evaluated locations reliably expressed the response of different genotypes to different locations. These data were corroborated by the observed selection accuracy (Table 2), which indicates the accuracy in the assessment of the genotypic value of the plants based on the phenotype (Resende and Duarte 2007).

The variation rate (IV) indicates a predominance of the genotypic over the experimental variation (Table 2). Moreover, it should be noted that the $\mathrm{CV}$ values were consistent with those proposed by Scapim et al. (1995) in experiments with corn. In fact, the index of variation (IV) was higher than 1 for most traits, except for DFF, ED and NEAP. In this context, it can be seen that the environmental effects at the evaluation locations were not predominant or did not affect the genetic variability of the genotypes under evaluation.

The average yield of genotypes was generally higher at the location "Colégio Agrícola" than at "Pesagro" (Table 3). The comparison of the plant means of each group at each location however showed the difference in yield between the super-sweet donor parents, of which parent $\mathrm{SH}_{2} 8 \mathrm{HS}$ was highest-yielding (Table 3).

The yield drop of the super-sweet genotype $\mathrm{SH}_{2}$ Piranão is also noteworthy, with the lowest yield, mainly in "Pesagro", which may be related to the differences in DENS observed in the group of super-sweet intervarietal hybrids (Table 3), which was related to the low germination in genotypes with the super-sweet trait.

Table 4. Means and $\mathrm{F}$ values of orthogonal contrasts for eight morphological characteristics evaluated in five distinct groups of Zea mays L. genotypes, in two growth locations (Colégio Agrícola e Estação Experimental da Pesagro), in the county of Campos dos Goytacazes

\begin{tabular}{|c|c|c|c|c|c|c|}
\hline \multirow[b]{2}{*}{ Morpho-agronomic traits } & \multicolumn{3}{|c|}{ SSH vs PBSS } & \multicolumn{3}{|c|}{ SSH vs FCH } \\
\hline & $\begin{array}{l}\text { Mean 10 } \\
\text { Group }\end{array}$ & $\begin{array}{l}\text { Mean } 2^{\circ} \\
\text { Group }\end{array}$ & Contrasts & $\begin{array}{l}\text { Mean } 1^{\circ} \\
\text { Group }\end{array}$ & $\begin{array}{l}\text { Mean 20} \\
\text { Group }\end{array}$ & Contrasts \\
\hline $\mathbf{P H}$ & 178.33 & 169.45 & $9.28 * *$ & 178.33 & 159.16 & $28.87 * *$ \\
\hline DFF & 80.03 & 80.34 & 0.12 & 80.03 & 75.44 & $17.37 * *$ \\
\hline YIELD & 35.40 & 27.45 & $61.70 * *$ & 35.40 & 35.91 & 0.17 \\
\hline NEP & 54.59 & 48.41 & $9.70 * *$ & 54.59 & 60.00 & $4.94 *$ \\
\hline NEAP ${ }^{1}$ & 5.28 & 5.78 & 0.32 & 5.28 & 4.75 & 1.78 \\
\hline \multirow[b]{2}{*}{ Morpho-agronomic traits } & \multicolumn{3}{|c|}{ PBSS vs SSPD } & \multicolumn{3}{|c|}{ PBSS vs FCP } \\
\hline & $\begin{array}{l}\text { Mean 1 } \\
\text { Group }\end{array}$ & $\begin{array}{l}\text { Mean } 2^{\circ} \\
\text { Group }\end{array}$ & Contrasts & $\begin{array}{l}\text { Mean 1' } \\
\text { Group }\end{array}$ & $\begin{array}{l}\text { Mean } 2^{\circ} \\
\text { Group }\end{array}$ & Contrasts \\
\hline EL & 20.09 & 18.92 & $20.53 * *$ & 20.09 & 19.58 & $5.95 * *$ \\
\hline ED & 25.93 & 27.57 & $10.83^{* *}$ & 25.93 & 25.14 & $3.70 *$ \\
\hline NEP & 48.41 & 54.19 & $5.65^{*}$ & 48.41 & 64.16 & $62.85^{* *}$ \\
\hline NEAP ${ }^{1}$ & 5.78 & 9.06 & $9.98 * *$ & 5.78 & 4.38 & $5.89 * *$ \\
\hline
\end{tabular}

$\mathrm{SSPD}=$ Super-sweet parent donors; $\mathrm{FCP}=$ field corn populations; $\mathrm{FCH}=$ field corn hybrids; $\mathrm{PBSS}=$ parents backcrossed to super-sweet corn; $\mathrm{SSH}=$ super-sweet hybrid; $\mathrm{PH}=$ plant height; $\mathrm{EL}=$ ear length; $\mathrm{ED}=$ ear diameter; $\mathrm{DFF}=$ days to female flowering; $\mathrm{DENS}=$ number of plants per plot; NEP = number of ears per plot; $\mathrm{NEAP}=$ number of ears attacked by pests; YIELD = yield $\left(\mathrm{t} \mathrm{ha}^{-1}\right)$; ${ }^{1}$ Data transformed to $(\mathrm{x}+0.5)^{1 / 2}$ for analysis of variance; *, ** significant at 5 and $1 \%$ probability by the $\mathrm{F}$ test. 
Comparing the group means of average yield, it is worth emphasizing the similarity between the super-sweet hybrid corn hybrids and the field corn populations (Table 3 ). This conformity between super-sweet hybrids and field corn hybrids indicates heterotic effects as a consequence of the interbreeding between parents backcrossed to supersweet corn.

The orthogonal contrasts among the five genotype groups under study (Table 4) showed the superiority of the super-sweet hybrids over super-sweet backcrossed parents, corroborating the hypothesis of heterosis resulting from interbreeding between the super-sweet backcrossed parents. It was also observed that the YIELD of the super-sweet corn intervarietal hybrids were comparable with those of field corn intervarietal hybrids (Table 4), indicating the effectiveness of backcrossing in the recovery of the respective recurrent genomes. It is worth mentioning the low NEP of the super-sweet corn intervarietal hybrids in contrast to field corn intervarietal hybrids, demonstrating that the YIELD of the super-sweet corn genotypes was the result of a greater ear weight, rather than of a higher number of ears.

The absence of differences in YIELD between donors of super-sweet corn and the parents backcrossed to super-sweet corn (Table 4) may be related to the low yield of genotype
$\mathrm{SH}_{2}$ Piranão, which is supported by the higher DENS value of the super-sweet donors parents. However, heterosis and similarity observed in the super-sweet intervarietal hybrids obtained from these backcrossed genotypes with the varieties CIMMYT and Piranão shows the possibility of obtaining genotypes of high value and highly adapted to the northern region of the State of Rio de Janeiro.

In view of the similar performance of the super-sweet corn hybrids and the intervarietal hybrids CIMMYT $8 \mathrm{x}$ Piranão 8, it was concluded that the super-sweet backcrossed parents $\mathrm{SH}_{2}$ CIMMYT, $\mathrm{SH}_{2}-8 \mathrm{HS}$ CIMMYT and $\mathrm{SH}_{2}-8 \mathrm{HS}$ Piranão are the most indicated to develop lines, with a view to establish high value hybrids in breeding programs, or even use them directly as commercial hybrids after further tests. The low germination rate of Piranão $\mathrm{SH}_{2}$ disqualifies this variety for breeding purposes, but its poor performance may be related to the low YIELD values observed for this genotype and DENS in general.

\section{ACKNOWLEDGEMENTS}

The authors thank the agricultural technician Geraldo Francisco de Carvalho for his valuable help with the crosses to establish the genotypes used in this experiment, and the Research Foundation of the State of Rio de Janeiro (FAPERJ) for financial support.

\section{Desempenho agronômico de genótipos de milho super-doce na região norte fluminense}

Resumo - Investigou-se o desempenho agronômico de genótipos de milho super-doce na região Norte Fluminense. Genótipos de milho super-doce foram retrocruzados com variedades de milho comum adaptadas a região (CIMMYT 8 e Piranão 8). Avaliaram-se oito características relacionadas à caracteres morfoagronômicos e rendimento de grãos. Houve efeito significativo de interação entre os cinco grupos de genótipos avaliados (Genitores Doadores, Parentais retrocruzados super-doce, Híbridos super-doce, híbridos de milho comum e populações de milho comum). A despeito do genótipo SH2 Piranão expressar baixo rendimento, os híbridos resultantes do intercruzamento entre os parentais retrocruzados se mostraram promissores no melhoramento do milho super-doce. O desempenho agronômico dos parentais super-doce e seus híbridos denota possibilidade de extração de linhagens com alto valor genético para obtenção de híbridos simples, bem como de cultivares de milho super-doce adaptadas a região Norte Fluminense.

Palavras-chave: Zea mays, milho super-doce, hibridos intervarietais, heterose, produtividade.

\section{REFERENCES}

Aragão CA, Dantas BF, Alves E, Cataneo AC, Cavariani C and Nakagawa J (2003) Atividade amilolítica e qualidade fisiológica de sementes armazenadas de milho super-doce tratadas com ácido giberélico. Revista Brasileira de Sementes 25: 43-48.

Assunção A, Brasil EM, Oliveira JP, Reis AJS, Pereira AF, Bueno LG and Ramos MR (2010) Heterosis performance in industrial and yield components of sweet corn. Crop Breeding and Applied Biotechnology 10: 183-190.

Barbieri VHB, Luz JMQ, Brito CH, Duarte JM, Gomes LS and Santana DG (2005) Produtividade e rendimento industrial de híbridos de milho doce em função de espaçamento e populações de plantas.
Horticultura Brasileira 23: 826-830.

Bordallo PN, Pereira MG, Amaral Júnior AT and Gabriel APC (2005) Análise dialélica de genótipos de milho doce e comum para caracteres agronômicos e proteína total. Horticultura Brasileira 23: 123-127.

Butrón A, Álvarez A, Revilla P, Malvar RA, Rodriguez VM, Galarreta JIR and Ordás A (2008) Agronomic performance of sweetcorn populations derived from crosses between sweetcorn and field corn. Journal of Agricultural Research 6: 378-384.

CONAB (2011) Segundo levantamento da safra de grãos 2011/2012. Available at http://www.conab.gov.br/OlalaCMS/ uploads/arquivos/11_11_09_15_03_02_boletim_2o_levantamento_ safra_2011_12.pdf. Accessed on 9 November 2011. 
PHAD Santos et al.

Fancelli AL and Dourado Neto D (2000) Produção de milho. Editora Agropecuária, Guaíba 360p.

Kwiatkowski A and Clemente E (2007) Características do milho doce (Zea mays L.) para industrialização. Revista Brasileira de Tecnologia Agroindustrial 1: 93-103.

Nigussie M and Saleh G (2007) Genetic variability and responses to two methods of recurrent selection in two sweet corn (Zea mays L. Saccharata) populations. Asian Journal of Plant Sciences 6: 859-863.

Oliveira Júnior LFG, Deliza R, Bressan-Smith RH, Pereira MG and Chiquiere TB (2006) Seleção de genótipos de milho mais promissores para o consumo in natura. Ciência e Tecnologia de Alimentos 26: 159-165.

Qi X, Zhao Y, Jiang L, Cui Y, Wang Y and Liu B (2009) QTL analysis of kernel soluble sugar content in super-sweet corn. African Journal of Biotechnology 8: 6913-6917.

Reis LS, Pereira MG, Silva RF and Meireles RC (2011) Efeito da heterose na qualidade de sementes de milho doce. Revista Brasileira de Sementes 33: 310-315.

Resende MDV and Duarte JB (2007) Precisão e controle de qualidade em experimentos de avaliação de cultivares. Pesquisa Agropecuária Tropical 37: 182-194.

Revilla P, Malvar RA, Ordás B, Rodriguez VM and Ordás A (2010) Genotypic effects on field performance of maize plants carrying the allele sugary 1. Plant Breeding 192: 92-95.

SAS Institute (1996) SAS/STAT: user's guide. SAS Institute, Cary, 1028p.

Scapim CAS, Carvalho CGP and Cruz CD (1995) Uma proposta de classificação dos coeficientes de variação para a cultura do milho. Pesquisa Agropecuária Brasileira 30: 683-686.

Teixeira FF, Sousa IRP, Gama EEG, Pacheco CAP, Parentoni SN, Santos MX and Meirelles WF (2001) Avaliação da capacidade de combinação entre linhagens de milho doce. Ciência e Agrotecnologia 25: 483488.

Tracy WF, Whitt SR and Buckler ES (2006) Recurrent mutation and genome evolution: example of Sugary1 and the origin of sweet maize. Crop Science 46: 1-7.

Welbaum GE, Frantz JM, Gunatilaka MK and Shen Z (2001) A comparison of the growth, establishment, and maturity of direct-seeded and transplanted sh2 sweet corn. Hortscience 36: 687-690. 